\title{
World's Knowledge Spillovers : Beyond Openness and Growth
}

C. Veeramani

Indira Gandhi Institute of Development Research, Mumbai, India

\begin{abstract}
Capital goods industries, for example, nuclear reactors, steam and vapour turbines, air or gas compressors, filtering or purifying machinery and apparatus are intrinsically heterogeneous in terms of vintages and the level of technological knowledge embodied in their products. Countries decide to import wide range of varieties from different sources, which has a bearing on their growth rates. The present paper analyses the hypothesis that the types of imported capital goods and the sources of their origin matter for growth. We construct a new index that measures the level of knowledge embodied in a country's import basket of capital goods. Using the instrumental variable method, we find that the high initial value of this index for the year 1995, leads to high growth rate of per capita income in the subsequent years during 1995 2005, that is, 10 percent increase in the value of the index raises growth rate by 2 to 3 percentage points. This paper looks beyond the simple relationship between trade openness and growth.
\end{abstract}

JEL Classifications: F10, F14, F43

Key words: Imports, Capital Goods, Growth, Knowledge Spillovers

\footnotetext{
* Corresponding Author: C. Veeramani; Indira Gandhi Institute of Development Research, Gen A K Vaidya Marg, Goregaon East, Mumbai-400065, India; Tel: +91 022 28416556, Fax: +91 022 28402752, E-mail: veeramani@igidr.ac.in. 


\section{Introduction}

As the world has become more integrated, increased attention has been focused on the question of whether trade integration promotes growth and what mechanisms underlie the relationship between the two. A widely held view is that international trade promotes growth via a transmission channel for knowledge spillovers across countries. This paper is concerned with the import composition of capital goods and its impact on growth rates.

In general, richer countries have a comparative advantage in producing knowledgeintensive capital goods since they are endowed with a higher stock of knowledge capital. Therefore, developing countries stand to gain more from trade integration with knowledge abundant countries.

Consistent with the above arguments, empirical studies show that the ratio of imported capital goods to domestic capital goods exerts a significant positive effect on the growth rates of per capita incomes, particularly in developing countries (Lee 1995, Mazumdar 2001). ${ }^{1}$ The mechanisms that drive this result include (i) imported capital goods being cheaper or of superior quality, (ii) imports of more differentiated inputs enhancing the productivity of final good production, and (iii) imports of capital goods and other specialized types of input acting as a transmission channel for cross-border knowledge spillovers.

Capital goods are heterogeneous in terms of their vintages and the level of embodied knowledge. Countries can potentially choose to import from wide varieties that are available in different sources and we show that this choice has a bearing on the importing country's growth rates.

Using finely disaggregated trade data, we construct an index (denoted as IMKNOW) that measures the level of knowledge embodied in a country's import basket of capital goods. Capital goods have been identified by matching trade data with the United Nation's codes of Broad Economic Categories (BEC). Specifically, our group of capital goods includes all 6-digit Harmonized System (HS) codes corresponding to BEC 41 (Capital goods, except transport equipments) and BEC 521 (Industrial transport

\footnotetext{
See also the theoretical papers by Chuang (1998) and Goh and Olivier (2002). Chuang formulates a trade-induced learning model to show that poorer countries derive benefits by importing knowledge-intensive richer country products. Goh and Olivier demonstrate that access to cheap but higher quality capital goods from developed countries enables a developing country to accumulate capital, which in turn stimulates learning by doing and higher growth.
} 
equipments). These industry set is composed of 639 capital goods, for example, tower cranes, bulldozers and angledozers, dairy machinery, chain saws, textile doubling or twisting machines, gas-operated machinery for welding. The main hypothesis tested is that the higher the initial IMKNOW value (for the year 1995) of a country, the faster is its subsequent (during 1995 2005) growth rate of per capita income and vice versa. It is likely that $I M K N O W$ is correlated with other variables that are relevant to growth, such as the absorptive capacity for new technology. To avoid endogeneity bias, we use instrumental variable method for estimating the impact of IMKNOW on the growth rate of GDP per capita. In order to choose the relevant instrumental variables, we draw upon the recent studies which emphasize the importance of commercial networks for international trade flows (Rauch 2001, Volpe Martincus et al. 2010) .

The econometric analysis strongly supports our hypothesis. The results imply that a 10 percent increase in the initial value of IMKNOW would raise growth by approximately 2 to 3 percentage points in the subsequent years. While capital goods are the major carriers of knowledge, intermediate manufactures (i.e., non-capital goods used as inputs in production) may also embody knowledge. We compute IMKNOW indices separately for capital goods and intermediate manufactures and show that, as expected, the former exerts a stronger impact on growth than the latter.

The remainder of the paper is structured as follows. Section II provides a brief review of the related literature. Section III describes the details of the methodology in the construction of the IMKNOW index. This section also provides a description of the data set used including descriptive analysis of IMKNOW. With a view to identify the instrumental variables, an analysis of the determinants of the IMKNOW index is attempted in Section IV. Section V discusses the econometric analysis of the impact of IMKNOW on the growth of GDP per capita. Section VI presents the results of sensitivity analysis. Finally, Section VII provides the concluding remarks.

\section{Related Literature}

The classical vintage capital models as well as some of the recent endogenous growth models predict a positive impact of embodied technical progress on economic growth. In accord with these models, some empirical studies suggest that continual introduction of new capital goods is a major driver of growth (DeLong and Summers 
1991, Wolff 1991). As mentioned above, some studies make a distinction between imported and domestically produced capital goods, and show, theoretically and empirically, that developing countries gain more from imported than domestically produced capital goods.

Certain strands of the open economy endogenous growth models provide a basis for our hypothesis that capital goods imports and their composition matters for growth. Bardhan and Pirale (1996) and Hsieh (2001) have formulated models that feature the endogenous obsolescence of existing capital goods as a result of the introduction of new varieties embodying the latest technologies. In these models, the new varieties of capital goods, however, do not completely replace the old varieties as many of the old varieties remain in use. ${ }^{2}$ These models suggest that the countries with shorter machine economic life grow faster than the countries where the life span of capital is longer.

Richer countries have a comparative advantage in introducing new varieties of capital goods that embody the latest technology since they are endowed with relatively higher stock of knowledge capital (Acemoglu and Zilibotti 1999) ${ }^{3}$. Poorer countries, however, can modernise their capital stock by importing new varieties of capital goods from the richer countries. In this context, it is pertinent to consider the composition of capital goods imports since old and new varieties can coexist in different countries. Wide varieties are potentially available for importing countries and clearly this choice has implications for growth rates.

Another strand of the models that provides a basis for our hypothesis is the innovation-based open economy endogenous growth models pioneered by Grossman and Helpman (1991). In these models, trade promotes the long-run growth rates of countries because it acts as a transmission channel for international technological spillovers. These models provide the theoretical basis for the empirical finding that trade liberalisation promotes growth as well as income convergence between countries (Ben-David and Loewy 2003).

Technological spillovers transmitted through trade can be of two types: rent spillovers and pure knowledge spillovers. Rent spillovers occur when the user of a new

\footnotetext{
${ }^{2}$ In this respect, these models are more realistic compared to other dominant models of endogenous growth pioneered by Romer (1990), Grossman and Helpman (1991), and Aghion and Howitt (1992). Romer's model considers the introduction of new varieties without affecting the productivity of existing varieties. The old varieties, therefore, never become obsolete and the wider the range of varieties (old and new) used, the better it is for productivity. On the other extreme, in the Schumpeterian models of Aghion and Howitt and Grossman and Helpman, new varieties completely and instantaneously replace the old varieties.

${ }^{3}$ Evidence suggests that some of the poor countries use old machines long after similar machines have been scrapped in richer countries (Pack 1988).
} 
and more knowledge-intensive product pays less for the product than its real worth. In contrast, pure knowledge spillovers stem from the nonrival and nonexcludable character of technology. For example, imports might facilitate learning about the products, inducing imitation or development of competing products. More generally, trade relationships help to establish and sustain communication channels, leading to crossborder learning. The crucial underlying point is that the potentials for import-induced rent and knowledge spillovers are essentially related to the knowledge intensity of the imported goods, which in turn, may depend on the sources of their origin. Countries that are more open to imports from partners with higher stock of knowledge, benefit more than those that are either closed to trade, or trade with partners with low levels of knowledge.

Coe and Helpman (1995) and Coe et al. (1997) have analyzed the empirical validity of import-induced knowledge spillover hypothesis, making use of a variable called foreign R\&D capital stock, defined as the weighted sum of the trading partner's R\&D stocks with aggregate bilateral import shares serve as weights. Regression analyses by these authors show that foreign R\&D capital stock exerts a significant positive effect on total factor productivity in both developed and developing countries. These studies, therefore, suggest that a country can benefit by importing goods from those source countries that have large cumulative experiences in R\&D. ${ }^{4}$

Many authors warn that the use of foreign R\&D capital stock constructed by using the aggregate import-share weights might lead to misleading interpretations. Aggregate import relations between countries are generally poor measures of trade in knowledgeintensive products that are the major carriers of international knowledge spillovers. Thus, the construction and interpretation of the foreign knowledge spillover variable remains a contentious issue (Falvey et al. 2002). ${ }^{5}$

Some studies, arguing that aggregate import-share weights are inappropriate, have tried to distinguish the knowledge content of imported products by using the import share weights of capital goods or of different types of machineries grouped at the 3-digit level of the Standard International Trade Classification. Xu and Wang (1999) and Blyde

\footnotetext{
${ }^{4}$ A number of studies note that foreign direct investment is also an important transmission channel for international technology spillover Blyde (2003). While both trade and foreign direct investment are important channels, Blyde (2003) finds that capital good imports exert a stronger effect on technology diffusion from industrial to developing countries.

${ }^{5}$ Using a number of alternative weighting schemes for the knowledge spillover variable, Falvey et al. (2002) analyze the presence of knowledge spillovers from the five leading OECD economies to a sample of 52 developing countries. They find that that volume of import is important in facilitating knowledge spillovers and that the effect is stronger when the weighting scheme considers knowledge spillover in the importing countries as a public good.
} 
(2003) calculate foreign R\&D stock using capital-goods import share as the weights. $\mathrm{Xu}$ and Wang (1999) find that this variable explains more of the cross-country variation in productivity than total imports weighted spillover variable. The study by Keller (2000) uses industry level data (at the 3-digit level) for machinery goods imports and shows that the use of disaggregated data matters a great deal for correctly interpreting the results.

This paper takes a further step in the direction of using more disaggregated data to differentiate the knowledge content of imported capital goods. The scale of knowledge heterogeneity in traded goods is far too large to be mirrored in data disaggregated by industries (Schott 2004, Broda et al. 2006). Thus, we try to capture knowledge heterogeneity across different varieties within capital goods industry. Following Broda et al. (2006), we take country of origin as the demarcation of a variety, e.g., we assume that television picture tubes produced in China, Germany, and South Korea are of different varieties.

\section{Measurement and Data}

\section{A. Measurement}

Using a quantitative index, denoted as $K N O W_{j k}$, we rank each variety, i.e., each 6 -digit item $k$ in each source country $j$ in terms of its implied knowledge intensity. The central idea intrinsic to the construction of this index is that richer countries hold a comparative advantage in producing the most knowledge-intensive varieties. Using the $K N O W_{j k}$ values, we construct another index, denoted as $I M K N O W$, which measures the extent of knowledge embodied in the capital goods import basket of country $i$. The $I M K N O W$ is simply defined as the import-weighted average of $K N O W_{j k}$ for importing country $i$. A relatively high value of IMKNOW implies that the given country's import basket is biased towards the knowledge-intensive varieties of capital goods, that is, the varieties with relatively high values of $\mathrm{KNOW}_{j k}$.

Hausmann, Hwang, and Rodrik (2007, henceforth HHR) have ranked traded products according to their implied knowledge level using a quantitative index denoted as $P R O D Y_{k}$. This index is a weighted average of the per capita GDPs of the countries exporting the given product $k$, where the weights are the revealed comparative 
advantages of each country in that product. HHR were interested in the hypothesis that a country's export composition matters for its growth and tested it. In their growth regression, they have included an index, denoted as EXPY that is the export weighted average of $P R O D Y_{k}$ for each country. The steps involved in the construction of our index $(I M K N O W)$ are similar to those proposed by HHR for constructing EXPY, but the indices themselves are completely different in purpose. Specifically, a high value of EXPY means that the country of interest exports goods with higher knowledge levels while a high value of IMKNOW suggests that the country's import basket is biased towards products with higher knowledge intensity. The knowledge intensity associated with the 6-digit product $k$ exported from country $j$ is defined as follows.

$$
K N O W_{j k}=R C A_{j k} Y_{j}
$$

where $Y_{j}$ is the per capita real GDP of country $j$ and $R C A_{j k}$ is the revealed comparative advantage of country $j$ in good $k$ defined as,

$$
R C A_{j k}=\frac{\left(x_{j k} / X_{j}\right)}{\sum_{j} x_{j k} / \sum_{j} X_{j}}
$$

The numerator of the $R C A$ index represents the value-share of $k$ in the overall export basket of country $j$. The denominator represents the value-share of $k$ in total world exports. ${ }^{6}$ If the $R C A$ value of $k$ in a country is greater than 1 , it implies that the country holds a comparative advantage in that product. The use of $R C A$ index as an adjustment factor, ensures that country size does not distort the ranking of products. Hausmann and Klinger (2006) notes that every country tends to have a specialized basket of exports and that the $R C A$ index captures all of its significant exports but leaves aside the noise.

Per capita real GDP has been taken as a proxy for a country's knowledge stock since richer countries tend to accumulate higher levels of knowledge capital (Acemoglu and Zilibotti 1999). Innovation of a new product is the result of a wide array of activities including $\mathrm{R} \& \mathrm{D}$, production engineering, workforce skills, managerial practices, venture capital, quality control, and troubleshooting. Richer countries are in a position to devote more resources to acquire these elements that are essential for continually introducing

\footnotetext{
${ }^{6}$ This is the well-known Balassa (1965) index of $R C A$, where $X_{j}$ stands for overall exports (i.e., value of capital goods plus noncapital goods exports).
} 
new innovative products. Therefore, we use per capita income as a catch-all measure of a country's accumulated knowledge stock.

More specific indicators of knowledge creation, such as R\&D spending and patent applications, do not properly capture product innovation, which is a complex and multifaceted process encompassing creativity, invention, and commercialization. National innovation surveys, carried out in a number of countries, confirm that formal R\&D is only one type of input into innovation. These surveys also confirm that while the world's formal R\&D is highly concentrated in a handful of rich countries, several countries are actively engaged in product imitations, reverse engineering, and non-R\&D related innovative activities. ${ }^{7}$ Micro-based studies also suggest that the relationship between the commonly used indicators like R\&D and patent applications and the more direct measures of innovative output is not strong (Kleinknecht et al. 2002).

Our basic hypothesis is that a country stands to gain more if its import basket is biased towards the varieties with higher values of $\mathrm{KNOW}_{j k}$; that is, the varieties where the richer countries hold high $R C A$. The extent of knowledge embodied in a country's import basket is defined by,

$$
I M K N O W_{i}=\sum_{j} \sum_{k}\left(\frac{m_{i j k}}{M_{i}}\right) K N O W_{j k}
$$

This is a weighted average of $K N O W_{j k}$ for country $i$, where the weights are the value shares of product $k$ from country $j$ in the total imports of capital goods in country $i$. A higher value of IMKNOW implies that country $i$ 's import basket is relatively biased towards the varieties with higher values of $K N O W_{j k}$.

\section{B. Data}

Trade data, at the 6-digit level of Harmonised System (HS), comes from the United Nations COMTRADE database accessed through World Integrated Trade Solution

\footnotetext{
${ }^{7}$ Patent applications are no better measures either. A patent reflects new technical knowledge, but it is not necessary that this knowledge has a positive economic value. Pakes and Griliches (1980, p 378) warns that "patents are a flowed measure (of innovative output); particularly since not all innovations are patented and since patents differ greatly in their level of economic impact."

${ }^{8}$ Direct measures of innovative output pertains to (i) the products "new to the firm" (i.e., already known in the firm's market) and (ii) products "new to the firm's market" (i.e., not previously introduced by a competitor). Data on these direct measures of innovative output, however, are not available in a systematic and comparable basis across countries.
} 
(WITS) software. The value of exports and imports is measured in current US dollars. The WITS software provides a concordance between 6-digit HS codes and the United Nation's codes of Broad Economic Categories (BEC). We use this concordance table to identify the 6-digit HS codes belonging to the group of capital goods and intermediates. See the Data Appendix for details.

Even though trade data according to the HS system is available since 1992, the number of reporting countries varies from year to year. ${ }^{9}$ Because non-reporting of trade data is likely to be correlated with income, the $K N O W_{j k}$ index should be computed using data for a consistent sample of countries. We notice that 148 countries have consistently reported the export data in each of the years from 2001 to 2003 . While export data were available for 148 countries, real per capita income data for the year 1995 was available in the World Development Indicators (WDI) database for 133 of these countries. We have computed the $K N O W_{j k}$ indices for these 133 countries using real per capita income of countries in the year 1995 and average value of $R C A_{j k}$ for the period of 2001 2003. ${ }^{10}$

Computation of the IMKNOW index requires bilateral import data. Bilateral import data at the 6-digit level of HS for the year 1995 were available for 99 countries, $^{11}$ of which 9 countries do not have data on real per capita GDP for the period 1995 2005. The final data set used for the regression analysis included 90 countries, of which 66 belongs to the group of developing (low- and middle-income) countries and the remaining 24 are developed (high-income) countries.

\section{Country- and product- specific Knowledge intensity and Knowledge embodied in imported capital goods}

As expected, richer countries generally record higher $K N O W_{j k}$ values compared to poorer countries. Table 1 provides the list of the 25 countries with the largest (top group) as well as the smallest (bottom group) median values of $K N O W_{j k}$. It is clear that the top group includes all the high-technology manufacturing leaders in the OECD

\footnotetext{
${ }^{9}$ Data according to Standard International Trade Classification (SITC) is available for a longer period but at a more aggregate level. We prefer to use the data based on HS classification because a higher level of data disaggregation is obviously more desirable for our purpose; that is, to measure knowledge intensity at the level of varieties within an industry.

${ }^{10}$ We have also carried out the analysis using per capita income at market exchange rates. However, this does not affect any of our findings.

${ }^{11}$ We exclude the countries with population less than 1 million in 1995. The number of countries that have reported import data for the year 1994 is only 85 .
} 
while the members in the bottom group are mostly the poorest countries from Africa and Asia. The correlation coefficient between per capita income and the median values of $K N O W_{j k}$ is as high as 0.82 . This high correlation is not surprising since $K N O W_{j k}$ is simply the product of per capita income and $R C A$.

Though $K N O W_{j k}$ is strongly correlated to per capita income, there is no one-to-one correspondence between them. For example, though Germany is not the richest country in our sample (with a rank of 13 out of 133 countries), it records the highest median value of $K N O W_{j k}$, reflecting its comparative advantage in high technology industrial equipment. Other examples include China and India, which rank respectively $96^{\text {th }}$ and $100^{\text {th }}$ positions in terms of per capita income, but rank respectively $47^{\text {th }}$ and $63^{\text {rd }}$ in terms of median $K N O W_{j k}$. This reflects the fact that China and India, despite their relatively low per capita incomes, hold significant domestic capabilities in certain types of capital goods. $^{12}$

\footnotetext{
${ }^{12}$ Import substitution policies in China and India, which had been in vogue until the late 1970s, stressed on the development of their domestic capabilities in capital goods production.
} 
Table 1. World's Distribution of Knowledge Intensity

(Median value)

\begin{tabular}{|c|c|c|c|c|c|c|c|}
\hline \multicolumn{4}{|c|}{ Top Group: 25 Largest Values } & \multicolumn{4}{|c|}{ Bottom Group: 25 Smallest Values } \\
\hline Countries & Value & Countries & Value & Countries & Value & Countries & Value \\
\hline Germany & 28,893 & Canada & 7,225 & Sudan & 1 & Mongolia & 21 \\
\hline United States & 27,575 & $\begin{array}{c}\text { Belgium- } \\
\text { Luxembourg }\end{array}$ & 6,784 & Nigeria & 3 & Cameroon & 22 \\
\hline Italy & 26,430 & Singapore & 5,579 & Ethiopia & 5 & Azerbaijan & 22 \\
\hline Japan & 19,069 & Australia & 5,155 & Algeria & 5 & Mali & 24 \\
\hline Switzerland & 18,565 & Finland & 5,007 & Bangladesh & 7 & Cambodia & 25 \\
\hline $\begin{array}{l}\text { United } \\
\text { Kingdom }\end{array}$ & 17,304 & Hong Kong & 4,755 & Tanzania & 8 & Mozambique & 26 \\
\hline France & 15,619 & Korea Rep. & 3,292 & Malawi & 8 & $\begin{array}{l}\text { Papua New } \\
\text { Guinea }\end{array}$ & 27 \\
\hline Austria & 15,538 & Slovenia & 2,980 & $\begin{array}{c}\text { Syrian Arab } \\
\text { Rep. }\end{array}$ & 13 & Sri Lanka & 28 \\
\hline Netherlands & 11,625 & Norway & 2,728 & Niger & 14 & Morocco & 31 \\
\hline Sweden & 11,167 & New Zealand & 2,453 & Zambia & 15 & Iran & 42 \\
\hline Denmark & 11,044 & Poland & 2,167 & Madagascar & 15 & Honduras & 49 \\
\hline Spain & 9,304 & Greece & 2,116 & Côte d'Ivoire & 17 & Uganda & 55 \\
\hline Czech Rep. & 7,735 & & & Burundi & 17 & & \\
\hline
\end{tabular}

Figure 1 shows the scatter plot of IMKNOW against per capita GDP. These two variables are positively correlated (the correlation coefficient is 0.69 ), which implies that the richer (poorer) countries tend to import those varieties with higher (lower) $K N O W_{j k}$ values. ${ }^{13}$ Table 2 provides the list of the 25 countries with the largest (top group) as well as the smallest (bottom group) values of IMKNOW. It may be noted that the top group includes some of the fastest growing economies of the world such as China, India, Latvia, and Ireland. In general, during 1995 2005, the countries in the top group have

\footnotetext{
${ }^{13}$ A major outlier on the lower left hand side of the scatter plot is Kyrgyz Republic (KGZ), a land locked and a predominantly agrarian economy. The low IMKNOW value of KGZ relative to its per capita income is due to the fact that just three middle-income countries (Russia, Turkey, and Kazakhstan) account for over 70 percent of its imports of capital goods.
} 
recorded a higher average annual growth rate of per capita income compared to those in the bottom group. While as many as six countries in the bottom group such as Burundi, Central African Republic, Niger, Paraguay, Uruguay, and Zimbabwe, recorded negative growth rate.

Furthermore, countries in the top group are generally larger in size compared to those in the bottom group. It may also be noted that while as many as 13 countries in the bottom group are landlocked, no country is landlocked in the top group. In the next section, we argue that certain geographical characteristics of countries can be used as instruments to obtain the estimates of IMKNOW's impact on growth.

Figure 1. Positive Relationship between GDP per capita and Knowledge embodied in imported Capital goods

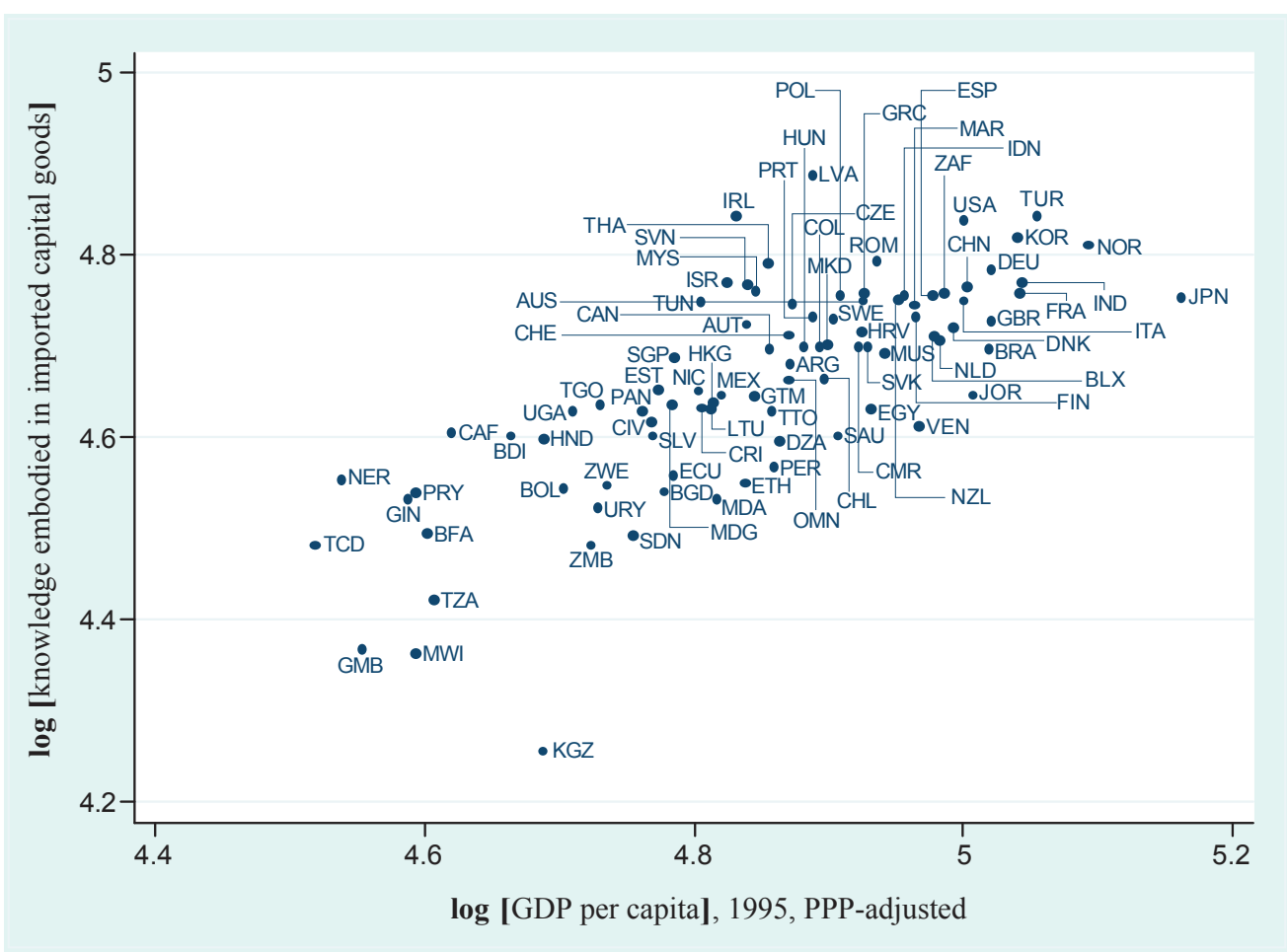


Table 2. World's Distribution of Knowledge embodied in imported Capital goods

\begin{tabular}{|c|c|c|c|c|c|c|c|}
\hline \multicolumn{3}{|r|}{ Top Group: 25 Largest Values } & \multicolumn{3}{c|}{ Bottom Group: 25 Smallest Values } \\
\hline Countries & Value & Countries & Value & Countries & Value & Countries & Value \\
\hline Latvia & 76,926 & Malaysia & 57,511 & Kyrgyz Rep & 17,960 & Bolivia & 34,854 \\
Ireland & 69,577 & Greece & 57,355 & Malawi & 23,065 & Zimbabwe & 35,211 \\
Turkey & 69,385 & South Africa & 57,318 & Gambia & 23,271 & Ethiopia & 35,392 \\
USA & 68,610 & France & 57,297 & Tanzania & 26,308 & Niger & 35,709 \\
Korea Rep & 65,946 & Spain & 57,010 & Chad & 30,200 & Ecuador & 36,182 \\
Norway & 64,540 & Indonesia & 56,815 & Zambia & 30,224 & Peru & 36,886 \\
Romania & 62,067 & Poland & 56,813 & Sudan & 30,973 & Algeria & 39,284 \\
Thailand & 61,607 & Japan & 56,495 & Burkina Faso & 31,272 & Honduras & 39,623 \\
Germany & 60,703 & New Zealand & 56,135 & Uruguay & 33,202 & Burundi & 39,813 \\
Israel & 58,716 & Australia & 56,078 & Moldova & 33,965 & Saudi Arabia & 39,901 \\
India & 58,611 & Italy & 56,078 & Guinea & 33,978 & El Salvador & 39,923 \\
Slovenia & 58,331 & Tunisia & 56,000 & Paraguay & 34,502 & Central & 40,105 \\
China & 58,101 & & & African Rep & \\
\hline
\end{tabular}

\section{Constructing Instruments}

Table 3 reports the cross-country OLS regression of IMKNOW. In order to choose the determinants of IMKNOW, we draw upon the gravity models and some recent studies which emphasize the importance of commercial networks for trade. ${ }^{14}$ Commercial networks promote trade by alleviating the problems of contract enforcement by reducing

\footnotetext{
${ }^{14}$ See Rauch (2001) for a survey of the studies on commercial (trading) networks. More recent evidences can be found in Volpe Martincus et al. (2010) and the reference therein.
} 
the search costs of trade and by providing information about trading opportunities. ${ }^{15}$ Information-related impediments to trade are particularly larger for differentiated products (Volpe Martincus et al. 2010). In such products, the connection between the sellers and buyers is often the result of a costly and lengthy search process, which is strongly conditioned by proximity and pre-existing ties resulting in trading networks rather than markets (Rauch 1999, p 8). The transaction costs of international trade also vary across countries depending upon the country's chance and ability to create trading networks and its geographical proximity with potential suppliers. ${ }^{1}$

The volumes of bilateral trade between geographically closer countries tend to be higher due to lower search costs and other advantages arising from geographical proximity. We use a variable, wdistance, defined as the weighted sum of geographical distances from a given country to each of the high-income OECD countries, the weights being the latter's GDP. Given that the richer countries, on average, have higher $K N O W_{j k}$ values compared to the poorer countries, we expect that the farther a country is located from the high-income countries, the lower will be the value of its IMKNOW and vice versa. The logarithm of wdistance indeed yields a large and statistically significant negative coefficient in the IMKNOW regressions. The results indicate that a 10 percent increase in the distance from the high-income countries would reduce the IMKNOW value of a country's capital goods imports by about 1.1 to 1.5 percentage points.

Empirical studies generally show that the volume of a country's trade with a partner would be smaller if one or both the countries are landlocked. Due to their lack of direct access to the sea, the landlocked countries usually depend heavily on their neighbours for both exports and imports, which may reduce their IMKNOW values. Indeed, the dummy for landlocked countries, equivalent to 1 for landlocked countries and 0 otherwise, shows a statistically significant negative coefficient. The island dummy, equivalent to 1 for island countries and 0 otherwise, however, yields a positive coefficient.

\footnotetext{
${ }^{15}$ Rauch (1999) observed that international exchange of manufactured products does not occur in organized markets like those of primary commodities for manufactured products differ too much in their quality and characteristics and their quoted prices do not fully play their signalling function.

${ }^{16}$ Redding and Venables (2004) also show that geographical proximity to the supplier countries affects a country's ability to import the differentiated intermediate goods and capital equipments.
} 
Table 3. Determinants of Knowledge embodied in imported capital goods (Dependent variable: log [Knowledge embodied in imported Capital goods], PPP, 1995)

\begin{tabular}{|c|c|c|c|}
\hline & (1) & (2) & (3) \\
\hline Log [per capita income $]$ & $\begin{array}{c}0.160 \\
(0.063)^{* * *}\end{array}$ & $\begin{array}{c}0.147 \\
(0.057)^{* * *}\end{array}$ & $\begin{array}{c}0.157 \\
(0.054)^{* * *}\end{array}$ \\
\hline Log [human capital $]$ & $\begin{array}{c}0.010 \\
(0.072)\end{array}$ & $\begin{array}{l}-0.008 \\
(0.071)\end{array}$ & $\begin{array}{l}-0.035 \\
(0.070)\end{array}$ \\
\hline Rule of law index & $\begin{array}{l}-0.002 \\
(0.015)\end{array}$ & $\begin{array}{c}-0.008 \\
(0.017)\end{array}$ & $\begin{array}{c}-0.011 \\
(0.017)\end{array}$ \\
\hline Log $[$ trade/GDP ratio $]$ & $\begin{array}{l}-0.055 \\
(0.036)\end{array}$ & $\begin{array}{c}-0.062 \\
(0.037)\end{array}$ & $\begin{array}{c}0.027 \\
(0.045)\end{array}$ \\
\hline Landlock dummy & & $\begin{array}{c}-0.054 \\
(0.024)^{* *}\end{array}$ & $\begin{array}{c}-0.040 \\
(0.024)^{*}\end{array}$ \\
\hline Island dummy & & $\begin{array}{c}0.030 \\
(0.030) \\
\end{array}$ & $\begin{array}{c}0.051 \\
(0.031)^{*}\end{array}$ \\
\hline $\log [$ wdistance $]$ & & $\begin{array}{c}-0.133 \\
(0.055)^{* *}\end{array}$ & $\begin{array}{c}-0.146 \\
(0.053)^{* * *}\end{array}$ \\
\hline Log [population] & & & $\begin{array}{c}0.057 \\
(0.019)^{* * *}\end{array}$ \\
\hline Constant & $\begin{array}{c}4.145 \\
(0.162)^{* * *}\end{array}$ & $\begin{array}{c}4.942 \\
(0.329)^{* * *}\end{array}$ & $\begin{array}{c}4.440 \\
(0.394)^{* * *}\end{array}$ \\
\hline $\begin{array}{c}\text { Observations } \\
R^{2}\end{array}$ & $\begin{array}{c}90 \\
0.48\end{array}$ & $\begin{array}{c}90 \\
0.53\end{array}$ & $\begin{array}{c}90 \\
0.59\end{array}$ \\
\hline
\end{tabular}

(Notes) ( i ) Robust standard errors are in parentheses.

(ii) * Significant at 10 percent level, ** significant at 5 percent level, *** significant at 1 percent level.

(iii) Wdistance: the weighted sum of geographical weights with the weights being the high-income OECD countries' GDP

Finally, we consider the size (proxied by population) of the importing country. A higher population may imply a larger number of people being engaged in the search process across the world, leading to better information flows on trading opportunities. This, in turn, would increase the chance that the importing country would source products from relatively better sources; that is, from countries with relatively higher $K N O W_{j k}$ values. As expected, population enters the IMKNOW equation with a statistically significant positive coefficient.

The results suggest that per capita income continues to be an important determinant 
of IMKNOW even when all other covariates are included. Rule of law index and human capital proxied by secondary school enrolment ratio yield statistically insignificant coefficients suggesting that IMKNOW is not a proxy for the human capital endowment or the institutional quality of a country. Also, the results do not suggest any significant correlation between IMKNOW and trade/GDP ratio. ${ }^{17}$

In sum, certain geographical variables such as wdistance, landlocked dummy, island dummy, and country size are among the important determinants of IMKNOW. These variables can be used as instruments to obtain consistent estimates of the impact of IMKNOW on growth rates.

\section{Growth and Knowledge embodied in Imported Capital goods}

We now turn to discuss the cross-country regression results in which the average growth rate of per capita income during 1995 2005 is regressed on initial values of $I M K N O W$ and other regressors. The regression analysis by HHR has shown that EXPY exerts a positive influence on growth. It will be interesting to see if the positive impact of EXPY would still hold once the impact of IMKNOW is controlled and vice versa.

It is likely that $I M K N O W$ is correlated with omitted variables, such as the absorptive capacity for new technology, which are relevant to growth. The method of Instrumental Variables (IV) can be used to address omitted variable bias and other sources of endogeneity. Since the omitted variables are not expected to be correlated with the instruments, the effects of the former can be included in the error term. However, the OLS method should be preferred if IMKNOW is actually exogenous since, in that case, the IV estimator will be less efficient than the OLS (Wooldridge 2003). The endogeneity tests done by Durbin-Wu-Hausman and GMM- $C$ statistic however, led to

\footnotetext{
${ }^{17}$ We have experimented by including the $E X P Y$ index of HHR in the $I M K N O W$ regressions. Though the actual values of $E X P Y$ fails to achieve statistical significance, its predicted values, obtained by regressing EXPY on log population and log land area, enter the $I M K N O W$ regression with a statistically significant positive coefficient (not reported). We have selected population and land area for obtaining the predicted values of EXPY because HHR has used these variables as instruments for estimating the effect of EXPY on the growth rate. That the cross country values of IMKNOW and EXPY are likely to be related and influenced by similar factors (such as population) is an aspect to be kept in mind while analyzing the independent effect of these indices on income growth.

${ }^{18}$ The regressions shown in Table 3 have also been run replacing the $I M K N O W$ values of capital goods with that of intermediates, but the results remain broadly the same (not reported).
} 
the rejection of the null hypothesis that IMKNOW is exogenous.

Tables 4 to 6 presents both the OLS and the IV-GMM results. The results confirm that the countries with low initial per capita income levels grow faster, thus supporting the conditional convergence hypothesis. As expected, human capital variable, rule of law index, and trade/GDP ratio show statistically significant positive coefficients.

The coefficient of log [initial EXPY] turns out to be positive in the OLS regressions (see Column 2 in Table 4), which is consistent with the findings of HHR. Column 3 reports the results after adding the initial values of EXPY and IMKNOW and both the indices show statistically significant positive effects, with the point estimate of the latter being higher than the former.

It may be noted that the Former Soviet Union (FSU) countries have experienced significant accelerations of income growth rates since the second half of the 1990s, subsequent to the initial contraction during the first half (Iradian 2007). ${ }^{20}$ In order to control this, we include the Former Soviet Union Dummy, equivalent to 1 for the FSU countries and 0 otherwise which shows a positive and statistically significant coefficient. Further, the overall goodness of fit of the regressions as well as the point estimates and $t$ values of IMKNOW improve significantly with the inclusion of this dummy.

\footnotetext{
${ }^{19}$ Following Wooldridge (2003), a further test for the endogeneity of IMKNOW has been conducted as follows. First, we obtained the residuals corresponding to the first stage regression in Table 3. Second, we re-estimated the OLS growth regressions after including these first stage residuals as explanatory variables. The coefficients of these residuals are statistically significant, further confirming that IMKNOW is indeed endogenous.

${ }^{20}$ The faster economic growth of the FSU countries, despite their relatively small initial IMKNOW values, may suggest that it may be important to include the FSU Dummy in the growth regressions. Studies suggest that the FSU countries exhibit a very strong "home bias" in trade both before and after the disintegration in comparison with what is typically found in the literature (Fidrmuc and Fidrmuc, 2003). The high intensity of "inter-republican trade" might mean that the imports of the FSU countries could be biased towards products with relatively small $K N O W_{j k}$ values. This is due to their greater imports from other FSU countries, most of which belong to the group of low and lower middle-income countries. Therefore, the FSU countries are likely to record relatively lower values of IMKNOW. Our experiments with the first stage regression in Table 3 show that the FSU dummy is negative and significant in the IMKNOW regression for intermediate manufactures though not significant for capital goods (not reported).
} 
Table 4. Cross-Country Growth Regressions

(Dependent variable: Growth rate of GDP per capita over 1995 2005)

\begin{tabular}{|c|c|c|c|c|c|c|}
\hline & (1) & (2) & (3) & (4) & (5) & (6) \\
\hline $\begin{array}{c}\log \\
\text { [initial per capita income] }\end{array}$ & $\begin{array}{c}-0.034 \\
(0.009)^{* * *}\end{array}$ & $\begin{array}{c}-0.045 \\
(0.011)^{* * *}\end{array}$ & $\begin{array}{c}-0.054 \\
(0.011)^{* * *}\end{array}$ & $\begin{array}{c}-0.050 \\
(0.012)^{* * *}\end{array}$ & $\begin{array}{c}-0.042 \\
(0.012)^{* * *}\end{array}$ & $\begin{array}{c}-0.040 \\
(0.012)^{* * *}\end{array}$ \\
\hline Log [human capital] & $\begin{array}{c}0.036 \\
(0.011)^{* * *}\end{array}$ & $\begin{array}{c}0.023 \\
(0.013)^{*}\end{array}$ & $\begin{array}{c}0.027 \\
(0.012)^{* *}\end{array}$ & $\begin{array}{c}0.023 \\
(0.013)^{*}\end{array}$ & $\begin{array}{c}0.016 \\
(0.013)\end{array}$ & $\begin{array}{c}0.009 \\
(0.013)\end{array}$ \\
\hline Rule of law index & $\begin{array}{c}0.010 \\
(0.004)^{* * *}\end{array}$ & $\begin{array}{c}0.010 \\
(0.004)^{* * *}\end{array}$ & $\begin{array}{c}0.010 \\
(0.003)^{* * *}\end{array}$ & $\begin{array}{c}0.011 \\
(0.004)^{* * *}\end{array}$ & $\begin{array}{c}0.009 \\
(0.003)^{* * *}\end{array}$ & $\begin{array}{c}0.010 \\
(0.004)^{* * *}\end{array}$ \\
\hline Log $[$ trade $/ G D P]$ & $\begin{array}{c}0.012 \\
(0.007)^{*}\end{array}$ & $\begin{array}{c}0.011 \\
(0.006)^{*}\end{array}$ & $\begin{array}{c}0.014 \\
(0.006)^{* *}\end{array}$ & $\begin{array}{c}0.015 \\
(0.007)^{* * *}\end{array}$ & $\begin{array}{c}0.010 \\
(0.006)^{*}\end{array}$ & $\begin{array}{c}0.014 \\
(0.006)^{* *}\end{array}$ \\
\hline $\log [$ initial EXPY] & - & $\begin{array}{c}0.020 \\
(0.009)^{* *}\end{array}$ & $\begin{array}{c}0.017 \\
(0.008)^{* *}\end{array}$ & $\begin{array}{c}0.020 \\
(0.009)^{* *}\end{array}$ & $\begin{array}{c}0.015 \\
(0.008)^{*}\end{array}$ & $\begin{array}{c}0.017 \\
(0.008)^{* *}\end{array}$ \\
\hline $\begin{array}{c}\text { Log [initial IMKNOW] } \\
\text { : capital goods }\end{array}$ & - & - & $\begin{array}{c}0.067 \\
(\mathbf{0 . 0 2 3})^{* * *}\end{array}$ & & $\begin{array}{c}0.073 \\
(0.019)^{* * *}\end{array}$ & - \\
\hline $\begin{array}{c}\text { Log [initial IMKNOW] } \\
: \text { intermediate goods }\end{array}$ & - & - & - & $\begin{array}{c}0.019 \\
(0.014)\end{array}$ & - & $\begin{array}{c}0.038 \\
(0.015)^{* * * *}\end{array}$ \\
\hline $\begin{array}{l}\text { Former Soviet Union } \\
\text { Dummy }\end{array}$ & - & - & - & & $\begin{array}{c}0.026 \\
(0.008)^{* * *}\end{array}$ & $\begin{array}{c}0.030 \\
(0.010)^{* * *}\end{array}$ \\
\hline Constant & $\begin{array}{c}0.063 \\
(0.030)^{* *}\end{array}$ & $\begin{array}{l}-0.060 \\
(0.049)\end{array}$ & $\begin{array}{c}-0.326 \\
(0.113)^{* * *}\end{array}$ & $\begin{array}{c}-0.140 \\
(0.076)^{*}\end{array}$ & $\begin{array}{c}-0.345 \\
(0.097)^{* * *}\end{array}$ & $\begin{array}{c}-0.214 \\
(0.079)^{* * *}\end{array}$ \\
\hline $\begin{array}{c}\text { Observations } \\
R^{2}\end{array}$ & $\begin{array}{c}90 \\
0.25\end{array}$ & $\begin{array}{c}88 \\
0.34\end{array}$ & $\begin{array}{c}88 \\
0.41\end{array}$ & $\begin{array}{c}88 \\
0.35\end{array}$ & $\begin{array}{c}88 \\
0.48\end{array}$ & $\begin{array}{c}88 \\
0.43\end{array}$ \\
\hline
\end{tabular}

(Notes) (i) Robust standard errors are in parentheses, OLS estimation

(ii) * Significant at 10 percent level; ** significant at 5 percent level; *** significant at 1 percent level

(iii) Growth rate of GDP per capita, PPP adjusted

Though the IMKNOW indices show the expected positive coefficients in the OLS regressions, a major concern, however, is that this variable could be endogenous. When a regressor is endogenous, the OLS estimator is inconsistent. We use the twostep efficient generalized method of moments (IV-GMM) estimator which is robust to heteroskedasticity of unknown form (Cragg 1983). Under heteroskedastic conditions, 
IV-GMM is more efficient than the simple 2SLS while the former is no worse asymptotically than the latter if heteroskedasticity is not present (Baum et al. 2003). Pagan-Hall and other tests in the IV context ${ }^{21}$ suggest that heterskedasticity is a problem in some of our regression specifications, which justifies the use of an IV-GMM estimator.

Table 5 reports the IV estimates of the impact of IMKNOW on growth using landlocked dummy, island dummy, and log [wdistance] as instruments. The relevance and validity of instruments can be checked by testing that the instruments are correlated with IMKNOW and are orthogonal to the error process. The degree of correlation to the endogenous variables is generally tested by looking at the $R^{2}$ of the first-stage regression after the included instruments and the associated $F$ test are "partialled out" (Bound et al. 1995). The $F$ tests and partial $R^{2}$ values reported in Table 5 indicate that the instruments are important and jointly significant in the first stage. Hansen's test of overidentifying restrictions (Hansen's $J$-statistic) suggests that the instruments are orthogonal to the error term and correctly excluded from the estimated equations.

It is clear that the IMKNOW indices enter the growth regression with large positive and statistically significant coefficients. Column 1 includes initial values of IMKNOW for capital goods in the growth regression along with the standard variables. The point estimate of IMKNOW in the IV-GMM regression is as high as 0.272 whereas the OLS regression yields a value of 0.067 . Other variables continue to show statistically and economically significant coefficients, with the point estimates of $\log$ [initial per capita income $]$ and $\log [$ trade/GDP] being larger in the IV regressions compared to the OLS.

${ }^{21}$ These tests are (i) Breusch-Pagan/Godfrey/Cook-Weisberg and (ii) White/Koenker. 


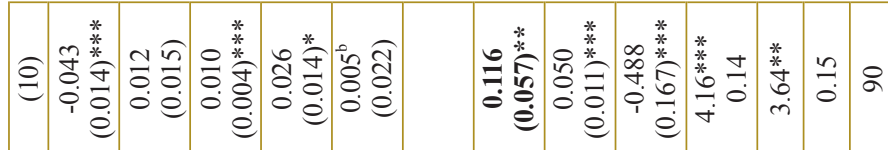

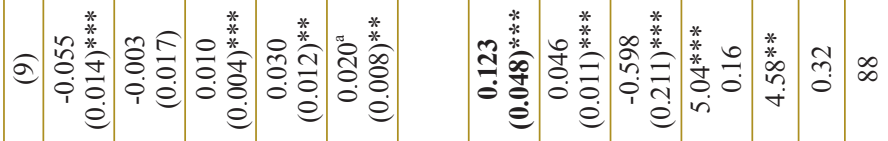

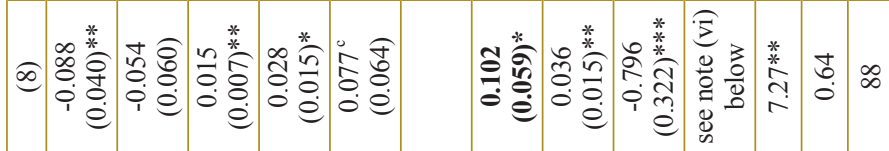

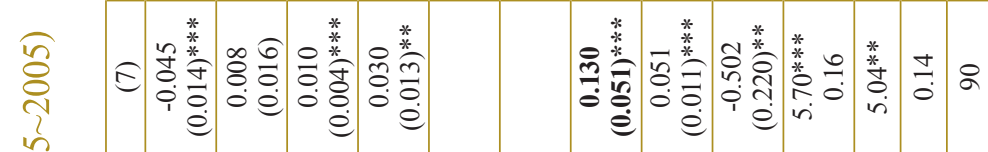

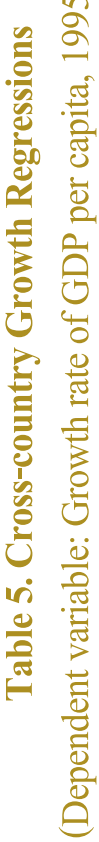

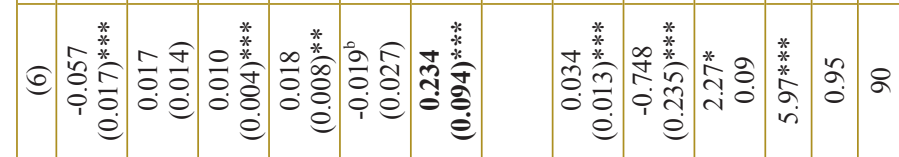

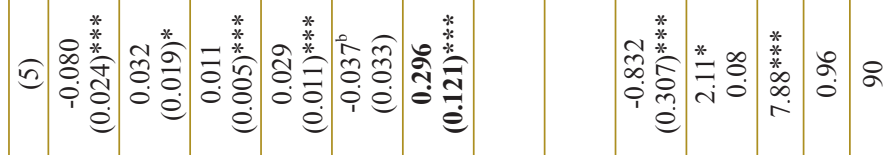

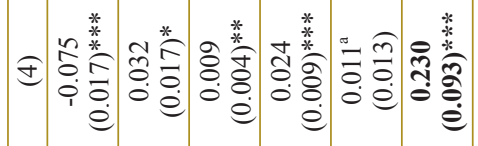

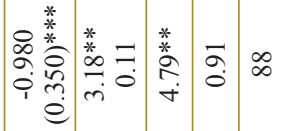

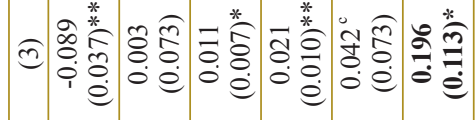

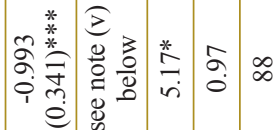

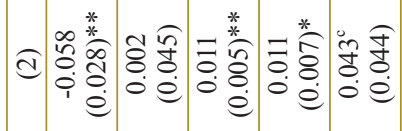

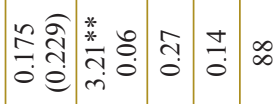

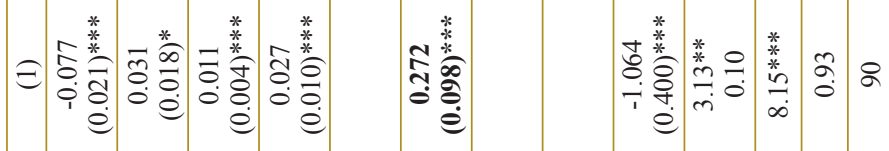

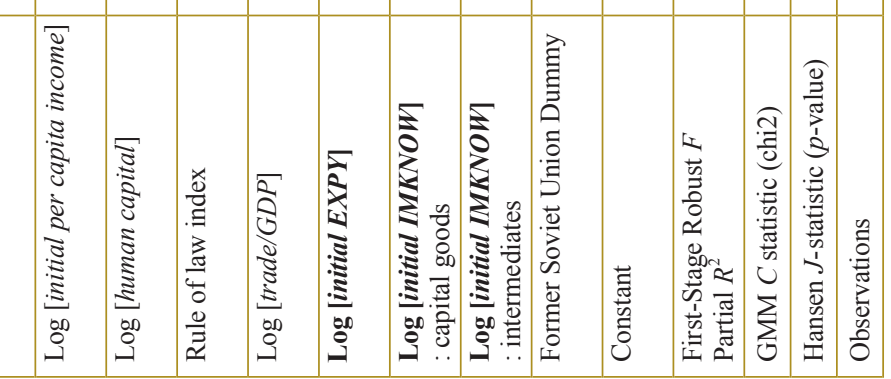

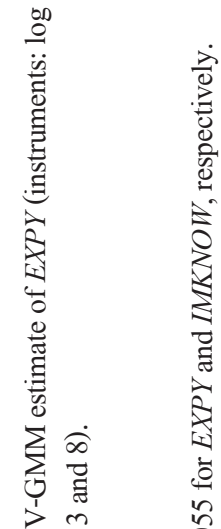
$\sum m \quad n$

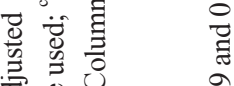

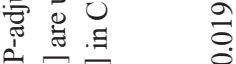

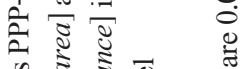

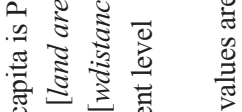

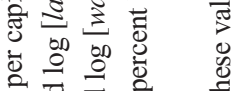

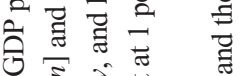

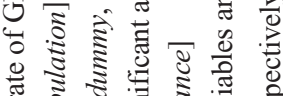

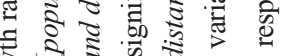

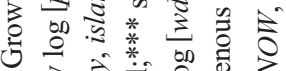

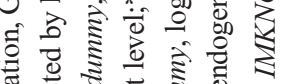

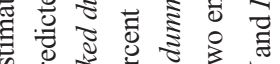
है

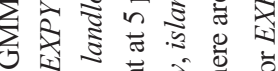

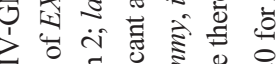

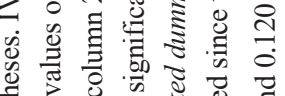

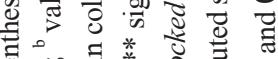

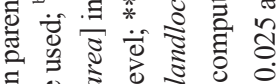

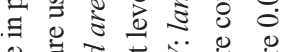
ปั

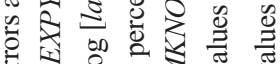

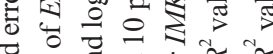
चु के है

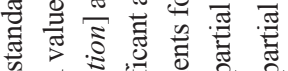

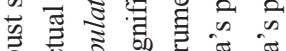

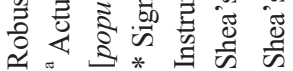
Э $\cong \Theta$ क्षे 
Column 2 shows the impact of EXPY where the instruments used are the same as those employed by HHR - log [population] and log [land area]. It is evident that the coefficient of EXPY, though positive, is not statistically significant in the IV-GMM regressions. $^{22}$ Other specifications in Table 5 consider the predicted as well as the actual values of EXPY, the predicted values being obtained by using log [population] and log [land area] as instruments. However, with the exception of the specification reported in Column 9, EXPY generally fails to achieve statistical significance at the acceptable level.

It is plausible that the values of IMKNOW and EXPY are influenced by similar factors. Therefore, we consider the possibility that the instruments used for estimating the causal effect of IMKNOW (landlocked dummy, island dummy, and log [wdistance] are relevant for EXPY as well and run IV-GMM regressions with two endogenous covariates (Columns 3 and 8, Table 5). Reassuringly, Shea's partial $R^{2}$ values suggest that these instruments are strongly correlated to IMKNOW while their correlation with EXPY is rather weak. ${ }^{23}$ The IMKNOW index in Columns 3 and 8 still retains statistical significance with correct sign while $E X P Y$ is not significant. These results, along with the possibility that EXPY and IMKNOW are interrelated, raise some serious doubts regarding the robustness of the finding by HHR that export composition exerts a significant positive effect on growth.

As expected, the point estimate of IMKNOW for capital goods in the IV-GMM regressions is significantly higher than that of intermediate manufactures. As shown in Table 5, the estimated coefficient of IMKNOW for capital goods varies from 0.20 to 0.30 while that of intermediate manufactures is about 0.10 to 0.13 . This result is consistent with the argument that knowledge spillovers from the imports of capital goods would be higher than from the imports of intermediate manufactures due to higher levels of knowledge embodied in the former. Taking the midpoint of the coefficient estimates, the results suggest that, ceteris paribus, a 10\% increase in IMKNOW for capital goods would raise growth by $2.5 \%$.

\footnotetext{
${ }^{22}$ The regressions run by HHR include all the explanatory variables included in Column 2 of Table 5 , with the exception of trade/ GDP ratio. The significance of $E X P Y$, however, does not improve even if we exclude trade/GDP ratio. The endogeneity tests (DurbinWu-Hausman and GMM $C$ statistic), however, fail to reject the null hypothesis that $E X P Y$ is exogenous. This means that, as far as the variable $E X P Y$ is concerned, the OLS estimator should be preferred over the IV since the former is more efficient than the latter when the regressor is exogenous. Indeed, the OLS regressions in Table 4 yield statistically significant positive coefficients for the EXPY index, whether IMKNOW is controlled for or not. However, the OLS estimate of EXPY is not significant in Table 5 (Column 4) where instrumental variables are used for IMKNOW.

${ }^{23}$ Shea's partial $R^{2}$ values for IMKNOW are 0.055 and 0.120 in Columns 3 and 8, respectively, while the corresponding values for EXPY are much smaller (i.e., 0.019 and 0.025 respectively).
} 
The scatter plot in Figure 2 represents a simple simulation analysis to quantitatively demonstrate the growth gains from increasing the IMKNOW values for the countries in our sample. The vertical axis of the figure corresponds to the predicted growth rates of per capita income assuming that all countries in the sample are able to achieve the US level of IMKNOW while keeping other independent variables fixed at their actual values, that is, hypothetical scenario. ${ }^{24}$ The horizontal axis represents the predicted growth rates keeping all independent variables, including $I M K N O W$, fixed at their actual values, which is actual scenario. For obtaining both sets of predicted values, we have used regression in coloum 6 of Table 5. In the scatter plot, the countries that lie further away from the 45 degree line represent those that would gain the most by moving towards the US level of IMKNOW values and vice versa. As expected, the group of developing countries stands to gain more than the group of developed countries. Comparing the predicted growth rates under the two scenarios, the hypothetical scenario yield a higher growth rate than the actual scenario by about 4.8 percentage points for the developing country group and by about 2.1 percentage points for the developed country group on average.

\footnotetext{
${ }^{24}$ We take the US as a benchmark since its IMKNOW is one of the highest (a notable exception is Latvia, see Table 2).

${ }^{25}$ We have experimented with the estimation of separate regressions for the sub-sample of developing countries, but find no statistically significant difference in the coefficient of $I M K N O W$ compared to the all-country sample.
} 
Figure 2. Predicted Growth: Hypothetical versus Actual knowledge embodied in imported Capital goods

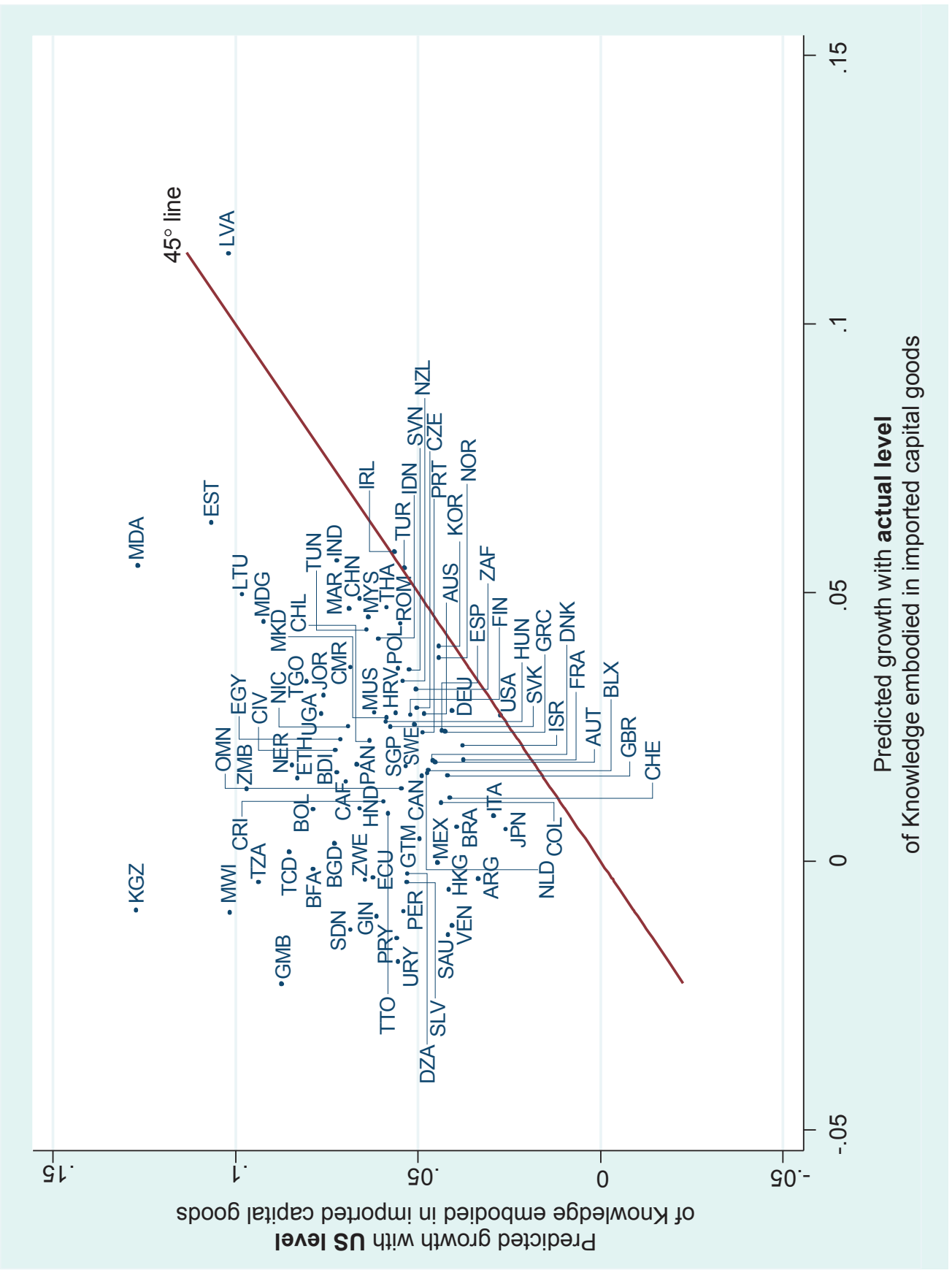




\section{Sensitivity Analysis}

In table 6, we run another set of IV-GMM regressions where population has been included as an additional instrument for IMKNOW for sensitivity analysis. It is clear that $I M K N O W$ continues to yield a high positive coefficient with statistical significance.

The first stage regressions reported in Table 3 suggest that population is a significant determinant of IMKNOW. However, in Table 5, we have not considered this as an instrument for estimating the impact of $I M K N O W$ for two reasons. First, as shown by HHR, population influences the values of EXPY as well. Second, many endogenous growth theories suggest the importance of scale effects though there exists no evidence that countries with higher population grow faster (Rose 2006, p 15). Again, we consider the actual and predicted values of EXPY, the latter being obtained using log [population] and $\log$ [land area] as instruments. While the actual EXPY values show correct signs with statistical significance, the predicted values continue to be insignificant.

In Columns 2 and 5, we consider the possibility that the whole set of instruments (landlocked dummy, island dummy, log [wdistance], log [population], and log [land area]) are relevant for both IMKNOW and EXPY and run IV-GMM regressions with two endogenous covariates. Overall, the results remain unchanged in that IMKNOW continues to show statistically and economically significant coefficients while EXPY remains statistically insignificant. 
Table 6. Cross-Country Growth Regressions for Sensitivity of Instruments

Dependent variable: Growth rate of GDP per capita, 1995 2005

Sensitivity: $\log$ [population] is additionally included as an instrument for IMKNOW

\begin{tabular}{|c|c|c|c|c|c|c|}
\hline & (1) & (2) & (3) & (4) & (5) & (6) \\
\hline $\begin{array}{c}\log \\
\text { [initial per capita income] }\end{array}$ & $\begin{array}{c}-0.053 \\
(0.011)^{* * *}\end{array}$ & $\begin{array}{l}-0.027 \\
(0.033)\end{array}$ & $\begin{array}{c}-0.052 \\
(0.014)^{* * *}\end{array}$ & $\begin{array}{c}-0.054 \\
(0.013)^{* * * *}\end{array}$ & $\begin{array}{c}-0.057 \\
(0.019)^{* * *}\end{array}$ & $\begin{array}{c}-0.044 \\
(0.013)^{* * *}\end{array}$ \\
\hline Log [human capital] & $\begin{array}{l}0.022 \\
(0.013)^{*}\end{array}$ & $\begin{array}{c}0.068 \\
(0.069)\end{array}$ & $\begin{array}{c}0.019 \\
(0.013)\end{array}$ & $\begin{array}{c}0.003 \\
(0.013)\end{array}$ & $\begin{array}{l}-0.001 \\
(0.022)\end{array}$ & $\begin{array}{c}0.011 \\
(0.014)\end{array}$ \\
\hline Rule of law index & $\begin{array}{c}0.008 \\
(0.003)^{* * *}\end{array}$ & $\begin{array}{c}0.004 \\
(0.007)\end{array}$ & $\begin{array}{c}0.010 \\
(0.003)^{* * * *}\end{array}$ & $\begin{array}{c}0.010 \\
(0.003)^{* * *}\end{array}$ & $\begin{array}{c}0.010 \\
(0.004)^{* * *}\end{array}$ & $\begin{array}{c}0.010 \\
(0.004)^{* * * *}\end{array}$ \\
\hline Log $[$ trade/GDP] & $\begin{array}{l}0.014 \\
(0.006)^{* * *}\end{array}$ & $\begin{array}{c}0.015 \\
(0.011)\end{array}$ & $\begin{array}{l}0.017 \\
(0.007)^{* *}\end{array}$ & $\begin{array}{c}0.025 \\
(0.008)^{* * * *}\end{array}$ & $\begin{array}{c}0.024 \\
(0.010)^{* * *}\end{array}$ & $\begin{array}{l}0.027 \\
(0.012)^{* *}\end{array}$ \\
\hline $\log [$ initial EXPY] & $\begin{array}{l}0.014^{\mathrm{a}} \\
(0.009)^{*}\end{array}$ & $\begin{array}{c}0.044^{\mathrm{c}} \\
(0.078)\end{array}$ & $\begin{array}{l}-0.010^{\mathrm{b}} \\
(0.022)\end{array}$ & $\begin{array}{c}0.021^{\mathrm{a}} \\
(0.008)^{* * *}\end{array}$ & $\begin{array}{l}0.026^{\mathrm{c}} \\
(0.027)\end{array}$ & $\begin{array}{l}0.004^{\mathrm{b}} \\
(0.019)\end{array}$ \\
\hline $\begin{array}{c}\text { Log } \\
\text { [initial IMKNOW } \\
\text { capital }\end{array}$ & $\begin{array}{c}0.132 \\
(0.044)^{* * *}\end{array}$ & $\begin{array}{c}0.237 \\
(\mathbf{0 . 1 4 3})^{*}\end{array}$ & $\begin{array}{c}0.193 \\
(0.070)^{* * *}\end{array}$ & & & \\
\hline $\begin{array}{c}\log \\
\left.\text { [initial IMKNOW }{ }_{\text {inter }}\right]\end{array}$ & & & & $\begin{array}{c}0.102 \\
(0.032)^{* * * *}\end{array}$ & $\begin{array}{c}0.100 \\
(0.044)^{* * *}\end{array}$ & $\begin{array}{c}0.119 \\
(0.048)^{* * *}\end{array}$ \\
\hline $\begin{array}{c}\text { Former Soviet Union } \\
\text { Dummy }\end{array}$ & $\begin{array}{c}0.027 \\
(0.008)^{* * *}\end{array}$ & $\begin{array}{c}0.039 \\
(0.017)^{* *}\end{array}$ & $\begin{array}{c}0.033 \\
(0.011)^{* * *}\end{array}$ & $\begin{array}{c}0.042 \\
(0.009)^{* * *}\end{array}$ & $\begin{array}{c}0.040 \\
(0.013)^{* * *}\end{array}$ & $\begin{array}{c}0.050 \\
(0.010)^{* * *}\end{array}$ \\
\hline Constant & $\begin{array}{c}-0.592 \\
(0.163)^{* * *}\end{array}$ & $\begin{array}{l}-0.730 \\
(0.283)\end{array}$ & $\begin{array}{c}-0.660 \\
(0.184)^{* * *}\end{array}$ & $\begin{array}{c}-0.507 \\
(0.144)^{* * *}\end{array}$ & $\begin{array}{c}-0.522 \\
(0.141)^{* * *}\end{array}$ & $\begin{array}{c}-0.493 \\
(0.162)^{* * *}\end{array}$ \\
\hline $\begin{array}{c}\text { First-stage Regression } \\
\text { Robust F Partial } R^{2}\end{array}$ & $\begin{array}{l}5.43^{* * *} \\
0.22\end{array}$ & see note $\mathrm{v}$ below & $\begin{array}{r}2.89 * * \\
0.15\end{array}$ & $\begin{array}{c}10.15 * * * \\
0.28\end{array}$ & $\begin{array}{l}\text { see note vi } \\
\text { below }\end{array}$ & $\begin{array}{l}6.34 * * * \\
0.19\end{array}$ \\
\hline GMM $C$ statistic (chi2) & 2.21 & $5.33^{*}$ & $5.45 * *$ & $4.54 * *$ & $5.62 *$ & $4.71 * *$ \\
\hline $\begin{array}{l}\text { Hansen } J \text {-statistic } \\
\quad(p \text {-value })\end{array}$ & 0.54 & 0.89 & 0.82 & 0.35 & 0.30 & 0.25 \\
\hline Observations & 88 & 88 & 90 & 88 & 88 & 90 \\
\hline
\end{tabular}

(Notes) ( i ) Robust standard errors are in parentheses, IV-GMM, Dependent variable is PPP-adjusted

(ii) a Actual values of EXPY are used; ${ }^{\text {b }}$ values of EXPY predicted by $\log$ [population] and $\log$ [land area] are used; ' IV-GMM estimate of EXPY (instruments: landlocked dummy, island dummy, log [wdistance], $\log$ [population], and $\log$ [land area]).

(iii) * Significant at 10 percent level; ** significant at 5 percent level;*** significant at 1 percent level

(iv) Instruments for IMKNOW: landlocked dummy, island dummy, log [wdistance], and log [population] in Columns 1, 3, 4, and 6; $\log$ [land area] is included as an additional instrument in Columns 2 and 5.

(v) Shea's partial $R^{2}$ values are 0.031 and 0.057 for EXPY and IMKNOW, respectively.

(vi) Shea's partial $R^{2}$ values are 0.059 and 0.127 for $E X P Y$ and $I M K N O W$, respectively. 


\section{Concluding Remarks}

Unremitting introduction of new capital goods is a major driver of growth. Most of the existing studies have analysed the role of aggregate capital goods on growth. Capital goods, however, are heterogeneous in terms of their vintages and level of embodied knowledge. This paper analyses the hypothesis that the types of imported capital goods and the sources of their origin matter.

Using highly disaggregated trade data, we construct an index, denoted as IMKNOW, to capture knowledge heterogeneity in different varieties within a given capital goods industry. Specifically, we test the hypothesis that, ceteris paribus, the higher the initial IMKNOW value (for the year 1995) of a country, the faster is its subsequent (during 1995 2005) growth rate of per capita income and vice versa. It is likely that $I M K N O W$ is correlated with other variables that are relevant to growth. The method of instrumental variables (IV-GMM) has been used to address omitted variable bias and other sources of endogeneity.

The econometric analysis strongly supports our hypothesis. The results imply that a 10 percent increase in the initial value of $I M K N O W$ for capital goods would raise growth by as much as about 2 to 3 percentage points in the subsequent years. We compute IMKNOW indices separately for capital goods and intermediate manufactures and show that the former exerts a stronger impact on growth than the latter: the estimated coefficient of IMKNOW varies from 0.20 to 0.30 for capital goods and from 0.10 to 0.13 for intermediate goods. This is consistent with the fact that capital goods embody higher levels of knowledge than intermediates. We also find that trade openness positively influences growth even after controlling for IMKNOW. On top of that, our results raise some serious doubts regarding the robustness of the finding by Hausmann et al. (2007) that export composition exerts a significant positive effect on growth. It is possible that their index is picking up the impact of import composition rather than export composition since they have not controlled the impact of the former.

The analysis in this paper sheds light on the mechanisms through which trade can influence the economic growth rates. It is important to look beyond the simple relationship between trade openness and growth. 


\section{References}

Acemoglu, Daron and Fabrizio Zilibotti (1999), "Information accumulation in development", Journal of Economic Growth, 4: 5-38.

Aghion, Philippe and Peter Howitt (1992), "A model of growth through creative destruction", Econometrica, 60: 323-351.

Balassa, Bela (1965), "Trade liberalization and revealed comparative advantage", Manchester School of Economics and Social Studies, 33: 99-123.

Bardhan, Pranab and Rodrigo Pirale (1996), "Endogenous growth theory in a vintage capital model", Working Paper No. 2408, Centre for International and Development Economics Research, University of California at Berkeley.

Baum Christopher F, Mark E Schaffer and Steven Stillman (2003), "Instrumental variables and GMM: estimation and testing", The STATA Journal, 3: 1-31.

Ben-David, Dan and Michael B. Loewy (2003), "Trade and the neoclassical growth model", Journal of Economic Integration, 18: 1-16.

Blyde, Juan S (2003), "The role of foreign direct investment and imports of capital goods in the North-South diffusion of technology", Journal of Economic Integration, 18: 545562.

Bound John, David A Jaeger and Regina M Baker (1995), "Problems with instrumental variable estimation when the correlation between the instruments and the endogenous explanatory variable is weak", Journal of the American Statistical Association, 90: 443450.

Broda, Christian, Joshua Greenfield and David E Weinstein (2006), "From groundnuts to globalization: structural estimate of trade and growth", NBER Working Paper, No 12512, September.

Chuang, Yih-chyi (1998), "Learning by doing, the technology gap and growth", International Economic Review, 39: 697-721.

Coe, David T and Elhanan Helpman (1995), "International R\&D spillovers", European Economic Review, 39: 859-887

Coe, David T, Elhanan Helpman and Alexander W Hoffmaister (1997), "North-south R\&D spillovers", The Economic Journal, 107: 134-149. 
Cragg, John G (1983), "More efficient estimation in the presence of heteroskedasticity of unknown form", Econometrica, 51: 751-763.

DeLong J Bradford and Lawrence H Summers (1991), "Equipment investment and economic growth", Quarterly Journal of Economics, 106: 445-502.

Falvey, Rod, Neil Foster and David Greenaway (2002), "North-South trade, knowledge spillovers and growth", Journal of Economic Integration, 17: 65-670.

Fidrmuc, Jarko and Jan Fidrmuc (2003), "Disintegration and trade", Review of International Economics, 11: 811-829.

Goh, Ai-Ting and Jacques Olivier (2002), "Learning by doing, trade in capital goods and growth", Journal of International Economics, 56: 411-444.

Grossman, Gene M and Elhanan Helpman (1991), "Innovation and Growth in the Global Economy", The MIT Press, Cambridge MA.

Hausmann, Ricardo and Bailey Klinger (2006), "Structural transformation and patterns of comparative advantage in the product space", Working Paper No.128, Centre for International Development, Harvard University.

Hausmann, Ricardo, Jason Hwang and Dani Rodrik (2007), "What you export matters", Journal of Economic Growth, 12: 1-25.

Hsieh, Chang-Tai (2001), "Endogenous growth and obsolescence", Journal of Development Economics, 66: 153-171.

Iradian, Garbis (2007), "Rapid growth in transition economies: growth-accounting approach”, IMF Working Paper, No. 07/164.

Keller, Wolfgang (2000), "Do trade patterns and technology flows affect productivity growth?", The World Bank Economic Review, 14: 17-47.

Kleinknecht, Alfred, Kees Van Montfort and Erik Brouwer (2002), “The non-trivial choice between innovation indicators", Economics of Innovation and New Technology, 11: $109-121$.

Lee, Jong-wha (1995), “Capital goods imports and long run growth", Journal of Development Economics, 48: 91-110.

Mazumdar, Joy (2001), "Imported machinery and growth in LDCs", Journal of Development Economics, 65: 209-224. 
Pack, Howard (1988), "Industrialization and trade", in Handbook of Development Economics, 1st edn (Eds) Hollis, B Chenery and T N Srinivasan, Vol 1, North Holland, Amsterdam, p. 333-380.

Pakes, Ariel and Zvi Griliches (1980), "Patents and R\&D at the firm level: a first report", Economics Letters, 5: 377-381.

Rauch, James E (1999), "Networks versus markets in international trade", Journal of International Economics, 48: 7-35.

Rauch, James E (2001), "Business and social networks in international trade", Journal of Economic Literature, 39: 1177-1203.

Redding, Stephen and Anthony J Venables (2004), "Economic geography and international inequality", Journal of International Economics, 62: 53-82.

Romer, Paul M (1990), "Endogenous technological change", Journal of Political Economy, 98: 71-102.

Rose, Andrew K (2006), "Size really doesn't matter: in search of a national scale effect", NBER Working Paper, No. 12191.

Schott, Peter (2004), “Across-product versus within-product specialization in international trade", Quarterly Journal of Economics, 119: 647-678.

Volpe Martincus, Christian, Antoni Estevadeordal, Andres Gallo and Jessica Luna (2010), "Information barriers, export promotion institutions, and the extensive margin of trade", Review of World Economics, 146: 91-111.

Wooldridge, Jeffrey (2003), “Introductory Econometrics: A Modern Approach”, South Western/Thomson Learning, Ohio.

Wolff, Edward N (1991), "Capital formation and productivity convergence over the long term", American Economic Review, 81: 565-579.

$\mathrm{Xu}$, Bin and Jianmao Wang (1999), "Capital goods trade and R\&D spillovers in the OECD”, Canadian Journal of Economics, 32: 1258-1274. 


\section{Appendix}

\section{A. Identification of Capital and Intermediate Goods}

A concordance between 6-digit Harmonized System (HS) codes and the United Nations' codes of Broad Economic Categories (BEC) is available in the World Integrated Trade Solution (WITS) database. We use this concordance table to identify the 6-digit HS codes belonging to the group of capital goods and intermediate goods follows. There are 639 HS 6-digit codes within the group of intermediate manufactures. These include, for example, automatic data processing machines, machines for manufacturing, spacecraft (including satellites), rail locomotives power by electric batteries, transformers electric power handling capacity, telephonic or telegraphic switching apparatus, radio navigational aid apparatus, cinematographic cameras, and fire fighting vehicles.

\begin{tabular}{|c|c|c|}
\hline Product Groups & $\begin{array}{l}\text { BEC } \\
\text { Codes }\end{array}$ & BEC Descriptions \\
\hline Capital Goods & $\begin{array}{l}\text { BEC } 41 \\
\text { BEC } 521\end{array}$ & $\begin{array}{l}\text { Capital goods, except transport equipments } \\
\text { Industrial transport equipments }\end{array}$ \\
\hline $\begin{array}{l}\text { Intermediate } \\
\text { Goods }\end{array}$ & $\begin{array}{l}\text { BEC } 22 \\
\text { BEC } 42 \\
\text { BEC } 53 \\
\text { BEC } 322\end{array}$ & $\begin{array}{l}\text { Processed industrial supplies, not elsewhere specified } \\
\text { Parts and accessories of capital goods, except transport } \\
\text { equipments } \\
\text { Parts and accessories of transport equipments } \\
\text { Other processed fuels and lubricants }\end{array}$ \\
\hline
\end{tabular}




\section{B. Data Sources}

\begin{tabular}{|c|c|}
\hline Variable & Data Source \\
\hline $\begin{array}{l}\text { Export and import values } \\
\text { (US\$ at the 6-digit level } \\
\text { of HS) }\end{array}$ & $\begin{array}{l}\text { United Nations' COMTRADE database accessed through } \\
\text { the World Integrated Trade Statistics (WITS) software }\end{array}$ \\
\hline $\begin{array}{l}\text { Real per capita income } \\
\text { (PPP-adjusted and } \\
\text { at market exchange rates) }\end{array}$ & World Development Indicators, World Bank \\
\hline $\begin{array}{l}\text { Secondary School } \\
\text { Enrolment Ratio }^{\text {a }}\end{array}$ & $\begin{array}{l}\text { Easterly, William R (2001) "Global Development Network } \\
\text { Growth Database" } \\
\text { at http://go.worldbank.org/ZSQKYFU6J0 and World } \\
\text { Development Indicators, World Bank }\end{array}$ \\
\hline Rule of law index ${ }^{b}$ & $\begin{array}{l}\text { Daniel Kaufmann, Aart Kraay, and Massimo Mastruzzi } \\
\text { (2007), "Governance Matters VI: Aggregate and Individual } \\
\text { Governance Indicators" World Bank Policy Research } \\
\text { Working Paper } 4280 \text { at www.govindicators.org }\end{array}$ \\
\hline Trade/GDP ratio ${ }^{c}$ & World Development Indicators, World Bank \\
\hline Population $^{\mathrm{d}}$ & World Development Indicators, World Bank \\
\hline $\begin{array}{l}\text { Landlock and } \\
\text { Island Status }\end{array}$ & $\begin{array}{l}\text { Easterly, William R (2001) "Global Development Network } \\
\text { Growth Database" and the "World Factbook," CIA website } \\
\text { at https://www.cia.gov/ }\end{array}$ \\
\hline wdistance $^{\mathrm{e}}$ & $\begin{array}{l}\text { Estimated using data downloaded from the CEPII website } \\
\text { at http://www.cepii.fr/anglaisgraph/bdd/distances.htm }\end{array}$ \\
\hline
\end{tabular}

(Notes) (i ) ${ }^{\text {a }}$ For a few countries, data are not available for the year 1995. In such cases, data for the closest year have been used.

(ii) ${ }^{b}$ These data are available for 1996, 1998, 2000, and annually for 2002 2006. We used the simple average for the period 1996 2005.

(iii) ${ }^{\mathrm{C}}$ Simple average for the period 1995 2005 has been used.

(iv) ${ }^{\mathrm{d}}$ Data for the year 1995 is used.

(v) ${ }^{\mathrm{e}}$ Great circle distance among the important cities of countries are used. 